\title{
MANAS DESTANI'NDA TÜRK KELIMESI VE AĞAÇ, KOYUN / KOÇ KÜLTLERİ
}

\section{Nurdin USEEV*}

\author{
Geliș Tarihi: Ekim, 2016
}

Kabul Tarihi: Aralık, 2016

\section{$\ddot{O} z$}

Türk dünyasının bin senelik destan geleneğini, tarihini, kültürünü ve dünya görüşünü kendi içinde barındıran Manas Destanı'nda, çağdaş Türk lehçelerinde kullanılmayan birçok kelime geçmektedir. $\mathrm{Bu}$ kelimelerin bazıları sadece belirli durumlarda söylenen kalıp metinlerde yer almaktadır. $\mathrm{Bu}$ kelimelerden biri de tarihî Türk lehçelerinde ve Klasik Türk Edebiyatı'nda güç, kudret, güçlü, güzel ve olgun anlamlarında kullanılan Türk kelimesidir. Söz konusu kelime Manas Destanı'nın söylendiği Kırgız Türkçesinde hiç görülmez. Hatta diğer Türk lehçelerinde de geçmemektedir. Ancak, geçmiş asırların kültürünü, inancını mısralarında korumuş olan Manas Destanı'nda Türk kelimesi bir etnonim olmaktan ziyade leksik anlama sahip bir cins isim olarak kullanılmaktadır. Destandaki Türk kelimesi güzel, iyi ve büyük anlamlarına gelmektedir. Güzel, iyi anlamlarını veren Türk kelimesi bir yerin güzelliğini yansıtmak için kullanılan ve iki yerde aynen tekrar edilen kalıp metinde geçmektedir. 'Biri terek, biri tal, Cigaçının türkü uşu (Biri kavak, biri sögüt, Ağaçların güzeli bu)' mısralarında, Türk kelimesi kavak ve söğüdün, ağaçların güzeli ve iyisi olduğunu ifade etmektedir. Bunun nedeni de söz konusu ağaçların kült anlamına sahip olmasıdır. Çünkü kavak ve söğüt ağaçlarının kendilerine ait özellikleri bulunmaktadır. Örneğin: Altay destanlarında Tanrı tarafından gönderilen kutlu kızlar, kavak ağacı vasıtasıyla yeryüzüne iner. Kavak, çocuk dileği için Tanrı'dan dilek dilenen kutlu mekân sembolüdür. Büyük anlamına gelen Türk kelimesi de kalıplaşmış mısralarda geçerek hep koyun, koç ve kuzu için kullanılmaktadır. Makalemizde bu durum koyun / koç kültü ile ilişkilendirilmiştir.

Çalışmada Türk kelimesinin geçtiği kalıp metinler ile birlikte kullanılan kelimeler ele alınarak Manas Destanı'ndaki Türk kelimesinin ağaç ve koyun / koç kültü ile ilişkili olduğu ortaya çıkarılmıştır.

Anahtar Sözcükler: Manas destanı, Türk kelimesi, ağaç kültü, koyun / koç kültü, kavak.

\section{THE WORD 'TÜRK' IN MANAS EPIC AND TREES, SHEEP / RAM CULTS}

\begin{abstract}
Manas Epic contains a thousand-year epic tradition, history, culture and world view of the Turkic world in itself. Therefore, there are many words unused today in modern Turkic languages, in this epic. Some of these words are only included in the pattern texts, said in a particular situations. One of these words is the word Turk. This word used in the historical Turkic languages and classical Turkish literature as a meanings power, strength,
\end{abstract}

\footnotetext{
Yrd. Doç. Dr.; Kırgızistan-Türkiye Manas Üniversitesi, Edebiyat Fakültesi, Türkoloji Bölümü, nuruseev@gmail.com.
} 
strong, beautiful and mature, never seen in Kirghiz Turkish. It is even not pass in other Turkic languages. However, the word Turk is used as a common noun with another lexical comprehension in the Manas Epic. The word Turk in the saga comes to nice and big meanings. The word Turk means beautiful is used in a two repeated pattern texts which reflects the beauty of a place. İn the verses 'Biri terek, biri tal, Cigaçının turku uşu (One of poplar, willow one, this is good for the trees)' the word Turk represents that the poplars and willows are the best of trees. The reason for this is that these trees means cults. Because poplar and willow trees have their own characteristics. For example, blessed girls are sent by God in the Altai epic, descends to earth through the poplar tree. Poplar is blessed place symbol of hope children, begging to God wishlist. The word Turk means big is used in formulaic verses only for sheeps, rams and lambs.

In our article, this case is associated with sheep / ram cults. In our article were examined pattern texts and other words, which pasts with the word Turk. As a result has been shown that the word Türk is associated with tree and sheep / ram cults.

Keywords: Manas Epic, the word Turk, tree cult, sheep / ram cult, poplar.

\title{
Giriş:
}

Hem hacmi hem de içeriğinin zenginliği açısından dünyanın en büyük destanlarından birisi sayılan Manas Destanı sadece Kırgızların değil, Eski Türk boylarının da kültürünü, inancını, dünya görüşünü, tarihini ve toplum düzenini yansıtan bir destandır ${ }^{1}$. Çünkü Kırgızlar, VII - IX. asırlar arasında kullandıkları Köktürk yazısını unuttukları ve Türk dünyasına daha sonra kazandırılan Arap yazısını belirli nedenlerle (yarı göçebe hayat tarzı sürmesi, önemli kültür ve siyasi merkezlerden uzak kalması $v b$.) yaygın olarak kullanmadıkları için kültürlerini, dünya görüşlerini, tarihlerini, önemli tarihî olaylar hakkındaki görüşlerini sözlü edebiyat ürünlerinde, özellikle destanlarında yaşatmaya çalışmışlardır. Bu konuda H. Geyikoğlu şunları belirtmektedir:

\begin{abstract}
Manas Destanı, çeşitli bilgileri ihtiva eden bir komplekstir. Burada tarih, etnografya, dil, felsefe, folklor, diplomasi, askerlik, halk pedagojisi, müzik kültürü, halk hekimliği gibi çeşitli konularda bilgiler geçmektedir. Manas Destanı, eski devirlerin hayatını yansıtması bakımından diğer destanlar arasında ayrı bir yer tutmaktadır. Destan, en az bin yıl önceki büyük Türk devletlerini kuran boy ve kabilelerin hayatını, gelenekgöreneklerini gözümüzün önünde canlandırmaktadır (Geyikoğlu, 2001: 204).
\end{abstract}

Manas Destanı'nın dili de oldukça zengindir. Çünkü söz konusu destanda bugün Kırgız Türkçesinde bulunmayan, ancak tarihî Türk lehçelerinde geçen kelimeler kullanılmaktadır. Örneğin: Orhun Yazıtları'nda yer alan ve türbe, mezarlık anlamına gelen bark kelimesi Kırgız Türkçesinde sadece Manas Destanı'nda geçmektedir. Bu tür kelimelerden biri de güzel, iyi ve

\footnotetext{
${ }^{1}$ Manas Destanı hakkında Türkçe yapılmış çalışmaların bibliyografyası için $b k$. İsakov, Abdrasul, Türkiyada 'Manas' Eposu Boyunça Basılgan Emgekterdin Bibliyografyası (1934-2014)', Uluslararası TEKE Dergisi, Say1 4/4, 2015 , s. 1451-1479. 
büyük kavramlarını karşılamak üzere kullanılan Türk kelimesidir. Türk kelimesi de bu anlamlarıyla sadece Manas Destanı'nda yer almaktadır.

Bilindiği gibi Türk kelimesi bir etnonim olmaktan ziyade bir cins ad olarak da leksik anlamlara sahiptir. Örneğin: Eski Uygurcada söz konusu kelime güçlü anlamına gelmektedir:

Türk burhanlarta kin intiniz (Güçlü burhanlardan sonra indiniz) (TT, III, 60; Nadelyayev, $v d .$, 1969: 599).

H. N. Orkun, Eski Uygurca metinlerde geçen

'ol ok teginmek tıltagınta ajunlarka ed tavarka, erkke türkke azlanmak turur (IŞste bu Vedana tarafindan sebebiyet verilmis olarak Trsanın hayata, mal ve mülke, iktidar ve kudrete karşı hissi tezahür eder)';

'iligler, begler, buyruklar, pürtükler, kunçuy katunlar, tigitler, 1nallar, ulug bay bayagutlar kentü erklerin türklerin 1dalap toyın dindar bolup arhant kutın bultılar (Hükümdarlar, beğler, buyruklar, pürtükler, prenses hanımlar, prensler, nazırlar, büyük ve zengin bayağutlar kendi kudret ve kuvvetlerini terk edip rahip, papaz olup rahat saadetinde oldular) cümlelerindeki Türk kelimesinin anlamından ve A. von Le Coq, Gyula Nemeth gibi bilim adamlarının çalışmalarından hareketle Türk kelimesinin güç, kuvvet, kudret anlamına geldiğini, daha sonra kavim adı olduğunu düşünmektedir (Orkun, 2011: 29-30). Söz konusu kelime Dîvânu-Lügâti 't-Türk'te vakit anlamına gelen bir kelime olup, meyvelerin olgunlaştığı zamanın ortasını, olgun, orta zamanı bildirmektedir:

türk üzüm ödi (Üzümün olgunluk vakti),

türk kuyaş ödi (gün ortası), türk yigit (gençlik çağının ortasına gelmiş genç) (DLT, I, 353; Ercilasin ve Akkoyunlu, 2014: 151).

\section{Güzel, İyi Anlamına Gelen Türk Kelimesi ve Destanda Ağaç Kültü}

Türk kelimesi Manas Destanı'nda Türk halklarını bildiren etnonim olmaktan ziyade leksik anlama sahip bir isim olarak ilk aşağıdaki metinde geçmektedir (S. Orozbakov, 369, 9750-9753):

\begin{tabular}{||l|l|}
\hline \multicolumn{1}{|c|}{ Manas Destanı (Özgün Metin) } & \multicolumn{1}{|c|}{ Türkiye Türkçesine Aktarımı } \\
\hline Biri terek, biri tal, & Biri kavak, biri söğ̈̈̈t, \\
Cigaçının türkü uşu, & A ğaçların güzeli bu, \\
Bir cıgaçta min uya, & Bir ăgaçta bin yuva, \\
Çınarının körkü uşu. & Dă̆ kavă̆ının güzelliği bu. \\
\hline
\end{tabular}

Yukarıda verilen metinde Türk kelimesi 'cıgaçının türkü uşu (Ağaçların güzeli bu)' cümlesinde geçerek ondan önceki mısrada anlatılan kavak ve söğüt ağaçlarını nitelemektedir. Tahlil edecek olursak türkü kelimesi, Türk ismi ile +ü III. şahıs iyelik ekinden oluşmaktadır. 
Çünkü bundan sonra gelen ve güzelliği anlamını veren körkü kelimesi de aynı yapıya sahiptir: körk (güzellik anlamına gelen kelime) +ü (III. şahıs iyelik eki).

Söz konusu metnin geçiş durumu şöyledir. Arkadaşları tarafindan han, hükümdar seçilen Manas, Altay etrafındaki yerleri gezerek ülke sınırlarını teyit etmek için arkadaşları ile sefere çıkar; bu sefer sırasında Orhun Nehri'nin yakınlarındaki bir yere gelirler ve bu yer hoşlarına gider. Çünkü bu yer ormanlık ve güzel olup, av hayvanları çoktur. İşte burası tasvir edilirken Türk kelimesi kullanılmaktadır. Metnin genelinde de Türk kelimesi güzel, iyi anlamlarında kullanılmaktadır. Çünkü burada kavak ve söğüt ağaçlarının diğer ağaçların içindeki özelliği, niteliği, yani güzelliği ve iyiliği anlatılmaktadır. İki yerde geçen bu ifade kalıplaşmış bir ifadedir. Yani bir yerin güzelliğini anlatmak için hazır bir şekilde kullanılan anlatı kalıbıdır. Formel ya da kalıp ifade adını da taşıyan bu yapılar destanlarda daha çok başlangıç, geçiş ve bitiş kalıpları şeklinde yer almaktadır. Ancak ele aldığımız metin destanın başlangıç, geçiş ve bitiş kalıpları ile ilişkili olmayan kalıp metindir. Bu şekildeki kalıp metinler icracı tarafından belirli bir durumu anlatmak için hazır bir şekilde kullanılan metinlerdir. K. Raihl, bu şekildeki kalıp ifadeleri destancının 'hafıza sanatının' bir kısmı olduğunu belirtmektedir (Raihl, 2008: 270). Bir başka deyişle, öteden beri destan metninde kullanılagelen kalıplardır. Bunun bir kanıtı söz konusu metinde geçen Türk kelimesidir. Türk kelimesi S. Orozbakov'un yaşadığı dönemde Kırgız Türkçesinde güzel, iyi anlamında kullanılmıyordu. Demek ki, ele aldığımız metin kalıplaşmış olduğu için Türk kelimesinin eski anlamını korumuştur.

Bu metinde kavak ve söğüt ağaçlarının güzel, iyi anlamlarına gelen Türk kelimesi ile nitelendirilmesini Türklerdeki ağaç kültü ile ilişkilendirebiliriz. Çünkü ağaç çok eskilerden beri Türk halklarında önemsenen ve kutsal sayılan bir tabiat unsuru idi. Örneğin: Uygurların Türeyiş Destanı'nda ana motif ağaçtır ve Uygurların dedeleri ağaçtan türemişlerdir. Bunun yanı sıra Altay Türklerinin mitolojisinde tepesinde Tanrı Bay-Ülgen oturan ve gökyüzüne doğru yükselen dünya ağacı ve Yakut Türklerinin mitolojisinde de sadece ilk insan değil, bütün canlıların beslendiği hayat ağacı vardı (Ögel, 1993: 88-96). O. Mert, Yakut mitolojisinde Tanrı'nın yarattığı üç kamın çadırlarının önüne üç ağaç dikerek kötü ruhlarla nasıl mücadele edeceklerini, insanlara nasıl yardımda bulunacaklarını bu ağaçların altında bildirdiğini belirterek şunları ifade etmektedir: Bundan dolayı dinî törenler, genellikle yeryüzüne Tanrı'nın getirdiğine inanılan kayın veya yıl boyunca yeşil kalan ardıç ve kara çam altında yapılır (Mert, 2009: 71). Ü. Gürsoy, P. Ergun'a gönderme yaparak Türk ve dünya kültüründe ağacın çağlar içinde birbirinden farklı pek çok rol oynadığını şöyle dile getirmektedir: 
Kozmik ağaç (dünya ağacı, hayat ağacı...), Tanrıyla iletişim aracı olarak ağaç, şeytan ya da kötü ruhları kovma törenlerinde ağaç, tabiat olaylarını yönlendirme törenlerinde ağaç, güneşin batışını engelleme ya da geciktirme törenlerinde ağaç, rüzgâr estirme ya da durdurma törenlerinde ağaç, ay tutulmasını engelleme ya da tutulan ayı kurtarma törenlerinde ağaç, yağmur yağdırma törenlerinde ağaç, sağaltma törenlerinde ağaç, defin törenlerinde ağaç, bereketi artırmaya yönelik mevsimlik törenlerde ağaç, şekil değiştirme ya da bitkilerin kökenleri ile ilgili mitlerde ağaç... Ayrıca mezarlara dikilen ağaçlar da ağaca atfedilen değerlerin bir ya da bir kaçının zaman süzgecinden geçerek günümüze kadar ulaşmış olduğunun bir başka işaretidir.

Kültürel yapıya ait çeşitli tabiat unsurlarına atfedilen kutsallığın önem kazandığı inanç sisteminde ağaç, yaşayışı şekillendiren önemli bir yapı unsurudur. Eski Türklerde medeniyetin beşiği olarak kabul edilen ağaca ve ağaç sevgisine çok önem verilir. Bu ağaçlar arasında kayın, çam, kavak ağacı, ardıç, çınar, dağ servisidir, servi-selvi, meşeemen, dut, söğüt, elma sayılabilir (Gürsoy, 2012: 44-45).

Belirtilen özelliklerinden dolayı ağaçlar, Eski Türklerin değer verdiği, kutsadiğ1 kavramları, nesneleri içeren kaya üstü tasvirlerde yer almakta ve bugün de Hakas, Kırgız, Altay, Azeri ve Türkiye Türklerinde üzerlerine bez bağlanarak kutsanmaktadır (Foto 1, 2). Bu konuda C. Alyılmaz şunları ifade etmektedir:

Türk dünyasının farklı bölgelerinde (Moğolistan, Tuva, Hakasya, Kırgızistan, Kazakistan, Doğu Türkistan...) yapmış olduğumuz araştırma ve incelemelerde birçok Türk boyu arasında 'ăgaçtan türeme' inancının hâlâ devam ettiğini, dallı budaklı, yaşlı ağaçlara olağanüstü özellikler atfedilip onlardan dilekte bulunulduğunu, 'ata ăgaç'ın (kimi bölgelerde 'ana ağaç'ın) temsilcisi olarak kabul edilen iri, gösterişli ve yaşlı ağaçların oboolara / ziyaretgâhlara çevrildğini ve bunlarla ilgili yılın belirli günlerinde özel törenler düzenlendiğini tespit ettik (Alyılmaz, 2016: 33).

$\mathrm{Bu}$ ağaçlardan ele aldığımız metinde geçen ve Türk kelimesi ile nitelendirilen kavak ve söğüt ağaçlarının kendilerine ait özellikleri bulunmaktadır. Örneğin: Altay destanlarında Tanrı tarafından gönderilen kutlu kızlar, kavak ağacı vasıtasıyla yeryüzüne iner. Kavak ağacı, kutlu erkek kahramanlarda olduğu gibi, kadın kahramanlarda da mucizevi dönüşüm sembolüdür. Kavak, çocuk dileği için Tanrı'dan dilek dilenen kutlu mekân sembolüdür. Mucizevi dönüşümü sağladığı için kavak ağacı mutluluk sembolüdür. Kavak ağacı, gelinle ilgili olarak bolluğun, bereketin, selametin ve esenliğin sembolüdür (Bars, 2014a: 387). Uygurlar arasındaki şamanların, ayinleri sırasında kullandıkları kutsal ağaç dalı söğüt dalından yapılmakta; peri oyunu adlı tedavi ayininin bir unsuru olan tuğa çeşitli renkteki kumaş parçaları ve elma dalından 
başka söğüt dalı da bağlanmakta; şaman kötü ruhları kovalamak için bir avuç söğüt ağacı parçası kullanmaktadır (Öğer ve Gönel, 2011: 240).

N. Yıldız, aşağıdaki metinden hareketle Manas Destanı'nda, söğüt ağacı ile Huda'nın ve Hızır'ın yâr olması, yani baht ve talih sahibi olup işlerinin rast gitmesi arasında bağ kurulduğunu, çınar ağacının da ata yurdu temsil ettiğini ifade etmektedir (Yıldız, 1998: 48-50).

\begin{tabular}{||l|l|}
\hline \multicolumn{1}{|c|}{ Manas Destanı (Özgün Metin) } & \multicolumn{1}{|c|}{ Türkiye Türkçesine Aktarımı } \\
\hline Bel aylana bergençe & Beli dolanınca \\
Beldey kızıl tal bütkön, & Bel gibi söğüt bitmiş, \\
Bir işiñ kuday car bütkön, & İşine Kuda yâr olmuş, \\
Üy aylana berginçe & Evi dolanınca \\
Üydöy kızıl tal bütkön, & Ev gibi söğüt bitmiş, \\
Koca Kıdır car bütkön. & Hoca Hızır yâr olmuş. \\
\hline
\end{tabular}

Böylece yukarıda dikkatlere sunulan metinde geçen Türk kelimesinin güzel, iyi anlamlarına geldiğini ve kavak, söğüt ağaçlarıyla ilgili inancı yansıttığını söyleyebiliriz. Söz konusu metin destanın III. kitabında da geçmektedir (S. Orozbakov, 294, 13876-13879):

\begin{tabular}{||l|l|}
\hline \multicolumn{1}{|c|}{ Manas Destanı (Özgün Metin) } & \multicolumn{1}{|c|}{ Türkiye Türkçesine Aktarımı } \\
\hline Biri terek, biri tal, & Biri kavak, biri söğüt, \\
Cigaçının türkü oşo, & A ğaçların güzeli o, \\
Bir cıgaçta mị uya, & Bir ăgaçta bin yuva, \\
Çınarının körkü oşo. & Dă̆ kavağının güzelliği o. \\
\hline
\end{tabular}

Gördüğümüz gibi verilen metin daha önce üzerinde çalışma yaptığımız metnin aynısıdır. Sadece uşu işaret zamirinin yerine oşo zamiri kullanılmıştır. İki yerde geçen bu dörtlük kalıplaşmış gibi mısralardır. Amacı belirli bir yerin güzel olduğunu bildirmektir. Bunun için de kült anlamı olan kavak, sögüt ağaçları yer almış, bu ağaçlar da güzel, iyi anlamına gelen Türk kelimesi ile nitelendirilmiştir. Bunun yanı sıra çınar ağacının güzelliği bir adet çınar ağacının budaklarında bin yuva olduğu belirtilerek anlatılmıştır. N. Yıldız, Çon Kazat sırasında Almambet'in kendi eliyle diktiği çınar ağacını görerek söylediği sözlerinden hareketle Manas Destanı'nda çınar ağacının ata yurdunu temsil ettiğini, insanoğlunun kaderini, kutsal bildiği bir ağaca bakarak tayin ettiğinin yer aldığını ve kurumuş çınar ağacının dibinden çıkan fidanların soyun devamının işareti olarak görüldügünü, bir başka deyişle olumlu fonksiyona sahip olduğunu belirtmektedir (Yıldız, 1998: 50). Yukarıdaki metinde çınar ağacının güzelliği ve iyiliğinin dallarında bin yuva barındırmasıyla yansıtılması aynı değeri taşımaktadır. Yani bu metinlerde çınar ağacı, budaklarındaki bin yuva ile ata yurdunu, neslin devamını ve hayatı sembolize etmektedir. 
Türk kelimesinin destandaki güzel, iyi anlamı söz konusu kelimenin orta asırlardaki Farsça kaynaklarda güzel anlamında geçmesi ile de örtüşmektedir. Türk kelimesinin güzel anlamında kullanılması Klasik Türk Edebiyatı eserlerinde de geçmektedir. Örneğin: 15. asrın ilk yarısında yaşayan Çağatay şairi Harezmli Hafız'ın Divanı'ndaki 'Eger dînsiz imes ol türk-i bed-kîş, Cefâ k̦1lmaķı cânġa bes nidindür (Ĕger o kötü huylu güzel dinsiz değilse cana cefâ kılması nedendir?)'; 'Ah uşol türk-i cefâkîşdin, Kim közin al kanıma ķıldı siyâh (Ah, o zalim güzelden ki al kanımı akttmak için gözünü kararttı)' gibi beyitlerde Türk kelimesi A. Üstüner'e göre etnik bir ismi de çağrıştırmakla beraber yüzyıllarca devam eden klasik edebî değerler açısından bakılınca güzel anlamında kullanılmıştır (Üstüner, 2014: 1111). Demek ki Manas Destanı'nda Türk kelimesinin eski anlamı korunmuştur.

\section{Büyük Anlamına Gelen Türk Kelimesi ve Destanda Koyun / Koç Kültü:}

Türk kelimesi Manas Destanında güzel, iyi anlamlarından başka büyük anlamında da geçmektedir:

\begin{tabular}{|c|c|}
\hline \multicolumn{2}{|c|}{ S. Orozbakov, II. kitap: 215, 9347-9354 } \\
\hline Manas Destanı (Özgün Metin) & Türkiye Türkçesine Aktarımı \\
\hline Cayılıp cürgön mal kördüm & Otlmakta olan hayvanları gördüm \\
\hline Canında cürgön can kördüm & Yanında bir canllyı gördüm \\
\hline Al candardı tạ kördüm. & O canlılara şaşırdım. \\
\hline Köz karaşı adamday, & Baklşları insan gibi, \\
\hline Körkün körsö itke okşoş, & Görünüşü köpek gibi, \\
\hline Koyun körsöm baarı türk & Koyunlarına baksam hepsi büyük \\
\hline Kozusun körsöm baarı irk, & Kuzularına bakarsam hepsi kısırlaştırılmış koç, \\
\hline Koydun eesin körsöm it. & Koyunun sahibine baksam o köpek. \\
\hline \multicolumn{2}{|c|}{ S. Orozbakov, VIII. kitap: 29, 1390-1394 } \\
\hline Manas Destanı (Özgün Metin) & Türkiye Türkçesine Aktarımı \\
\hline Bolgon sözdün baarın ayt & Olan sözün hepsini söyle, \\
\hline Bokmurun degen balama. & Bokmurun adlı oğluma. \\
\hline Kozusun saabay türk kilsın, & Kuzusunu sağmadan büyük yapsin (büyütsün), \\
\hline Koçkordu bıçıp irik kılsın, & Koçu hadım ederek kısırlaştırılmış koç yapsın, \\
\hline Aygırdı bıçıp at kılsın. & Aygırı hadım ederek kısırlaştırılmış at yapsın. \\
\hline \multicolumn{2}{|c|}{ S. Orozbakov, VIII. kitap: 54, 3240-3243 } \\
\hline Manas Destanı (Özgün Metin) & Türkiye Türkçesine Aktarımı \\
\hline Koçkordu bakkın türk bolsun, & Koçu besle, büyük olsun, \\
\hline Kozunu bakkın irik bolsun, & Kuzuyu besle, kısırlaştırılmış koç olsun, \\
\hline Taylaktı bakkın töö bolsun, & Tayı besle deve olsun, \\
\hline At bakpagan cöö bolsun. & At gütmeyen yaya olsun \\
\hline
\end{tabular}


Destanın üç yerinde biraz değişikliklerle tekrarlanan bir kalıp metin olan yukarıdaki metinlerde Türk kelimesi hep koyun ve koçlarla ilgili yer almaktadır. 'Koyun körsöm baarı Türk (Koyunlarına baksam hepsi büyük)' cümlesinde koyunların Türk olduğu anlatılmakta, 'Kozusun saabay Türk kılsın [Kuzusunu sağmadan büyük yapsin (büyütsün)]' cümlesinde koyunu sağmazsa kuzusu Türk olacağı belirtilmekte, 'Koçkordu bakkın Türk bolsun (Koçu besle, büyük olsun)' cümlesinde ise koçu beslerse Türk olacağı ifade edilmektedir. K. Yudahin'in sözlüğünde Türk kelimesi madde başı olarak ele alınmış ve örnek cümle niteliğinde yukarıdaki mısralar verilmiştir. Yani Kırgız Türkçesinde Türk kelimesi sadece Manas Destanı'nda geçmektedir. Söz konusu sözlükte Türk kelimesinin sadece koyunlar için kullanıldığı belirtilerek büyük ve yağlı anlamına geldiği ifade edilmiştir (Yudahin, II, 1985: 284). Verilen bu anlamlardan yağlı anlamı biraz şüphelidir. Çünkü Türk kelimesi geçen mısraların, metinlerin genel anlamından bu anlamı çıkarmak mümkün olmamaktadır. Bir başka deyişle bu metinlerde Türk kelimesinin sadece büyük anlamına geldiği anlaşılmaktadır. Belirtilmesi gereken husus Türk kelimesi ile verilen büyüklük maddi anlama sahip olarak hacim bakımından olan büyüklüğü bildirmektedir.

Türk kelimesinin destandaki büyük anlamını Eski Uygurcadaki güçlü, Dîvânu-Lügâti 'tTürk'teki vakit anlamına gelen ve meyvelerin olgunlaştığı zamanın ortasını, olgun, orta zamanı bildiren anlamıyla ilişkilendirmek mümkündür. Çünkü olgunluğun büyümeyle gerçekleşeceği, olgunlaşmış, büyümüş canlının güçlü olacağı biyolojik bir gerçektir. Dolayısıyla Manas Destanı'ndaki Türk kelimesinin Eski Türkçedeki Türk kelimesinin anlam değişikliğine uğramış devamı olduğunu ifade edebiliriz.

Bu metinlerde Türk kelimesi yukarıda belirtildiği gibi hep koyun, kuzu ve koçla ilgili geçmektedir. Kelimelerin kalıp metinlerin içindeki kullanımı, ne anlamda niçin kullanıldığı çok önemlidir. Çünkü kalıp ifadeler ve sözler toplumun kültürünü, inançlarını, insan ilişkilerindeki ayrıntıları, gelenek ve görenekleri yansıtır (Bars, 2014b: 293). Büyük anlamına gelen Türk kelimesinin Kırgız Türkçesinde sadece Manas Destanı'nda yer alan kalıp metinlerde ve sadece koyun, kuzu ve koç ile ilgili geçmesi söz konusu hayvanların kültsel özelliklerinden kaynaklanmış olabilir. Örneğin: Bokmurun, babası Kökötöy Kan'ın aşını (bir kişinin ölümünden bir ya da birkaç sene geçtikten sonra verilen toy, ziyafet) yapmak için hazırlıklara başlamaları gerektiğini anlatırken 'Koçkordu bakkın Türk bolsun (Koçu besle büyük olsun)' demektedir. Yani koçun belirli bir özelliği olduğu kesindir. Çünkü F. Türkmen, Azerbaycan'daki koç şekilli mezar taşlarının folklorik değerlendirmesini yaptığı makalesinde en önemli besin kaynağı hayvan, özellikle koç ve koyun olan Türklerin ve Moğolların bu ekonomik şartlarının büyülü dinî inançlarına da karıştığını, ilk önce inanç kaynağı olarak 
yüceltilen hayvanlardan bazıları, daha sonra insanın da ondan türediği gerçeğine kadar geliştiğini belirtmekte, koyun ve koç hakkında şunları ifade etmektedir:

Koyun ve koç sembollerinin eski Türklerde hangi sembolik anlamlar ifade ettiği konusu bilim adamlarını epeyce meşgul etmiştir. İslamiyet’ten önce Türkler Göktanrı'ya koyun ve koç kurban etmekte idiler. Kurban edilecek hayvanın Tanrı'ya layık olması, Tanrı tarafindan kabul edilebilecek özellikleri de olması gerekirdi. Beyaz koyun, Altaylarda, bugün bile göğe kurban edilmekte ve ağzı bağlı hâlde iken bağırırsa kurbanların kabul gördüğü anlamına gelmekteydi. Orta Asya'dan Balkanlara kadar Türk san'atının yaygın olduğu bölgelerde, XII-XIII. yy.dan itibaren at, koç ve koyun heykeline pek çok mezar taşında rastlanmaktadır (Türkmen, 2008: 505).

C. Alyılmaz, ister yabani ister evcil olsun koçun hem geçmişte hem de bugün Türk boy ve topluluklarında erkekliği, üretkenliği, bolluğu, bereketi; yiğitliği, yürekliliği, savaşç1lı̆̆ı, kahramanlığı, cesareti ve asaleti temsil ettiğini, bundan dolayı koç tasvirleriyle, damgalarıyla ve heykelleriyle $M O ̈$. dönemlerden bugüne kadar Türk boy ve topluluklarının yaşadıkları her bölgede karşılaşmanın mümkün olduğunu belirtmektedir (Alyılmaz, 2015: 479). Bu özelliklerinden dolayı Eski Türk kağanlarının türbelerinde koyun, koç ve kuzu heykelleri yer almaktadır (Foto 3, 4, 5). M. Aksoy, Kazakistan'da koçun erlik, yiğitlik ve bağımsızlık damgası olarak bilindiğini, eski zamanlarda Kazak askerlerinin dizlerinde, gögüslerindeki zırh parçalarında ve ellerindeki kalkanlarında koç damgası bulunduğunu ve Manas'ın türbesinin olduğu yerdeki saha araştırması sırasında aynı anlayışı tespit ettiğini, yani Manas'ın kalkanında, yayında, kuşandığı zırhında hep koçbaşı damgalarının bulunduğunu belirtmektedir (Aksoy, 2014: 132-134). N. Diyarbekirli, Hunlarda ve Hunlardan sonraki Göktürklerde de en önemli kurban hayvanları olarak at, dağ koyunu ve koçun yer aldığını, atın göğe, koyun ve koçun toprağa kurban verildiğini belirttikten sonra Kazak ve Kırgızlardaki türbe geleneğiyle ilgili şu inancı ifade etmektedir: Bundan başka gene bu türbenin yanında birkaç tane kesik koç kafası bulunurdu. Bu koçbaşları da o türbede önemli bir adamın, hatta bir mukaddes kimsenin yattığına delalet ederdi (Diyarbekirli, 1972: 92-94). B. Ögel, Türk destanlarında ve mitolojisinde koçun kurban hayvanı olarak yer aldığını belirtmektedir (Ögel, 1995: 544). Bundan hareketle destanda koçu besleyerek Türk (büyük) kılmak işte koçun Kökötöy gibi padişahın aşında kurban olarak kesilebilecek değerli hayvan olması inancından kaynaklandığını söyleyebiliriz. Koyunun ve koçun büyüklüğünün sadece Manas Destanı'nda bulunan kalıp metinlerde geçen Türk kelimesi ile verilmesi, başka canlıların Türk kelimesi ile nitelendirilmemesi ayrı bir öneme sahiptir.

Manas Destanı’ndaki koyun / koç kültüne ilişkin önemli hususlardan biri de Manas doğarken sarı alın saçlı gök koyunun sarı koç doğurmasıdır:

\section{TFp}

Uluslararası Türkçe Edebiyat Kültür Eğitim Dergisi Sayı: 5/4 2016 s. 1611-1626, TÜRKIYYE 


\begin{tabular}{|c|c|}
\hline \multicolumn{2}{|c|}{ S. Karalaev, 2010: 69.} \\
\hline Manas Destanı (Özgün Metin) & Türkiye Türkçesine Aktarımı \\
\hline Koluna koş koldop zaar karmadı. & İki eline zehir tuttu. \\
\hline Kursakta catıp bakırdı, & Karında yatıp bă̆ırdl, \\
\hline Munuy 'Manastap' uraan çakırdı. & Bunun 'Manas' diye nidâ söyledi. \\
\hline Sarı saamay kök koydo & Sarl gök koyunda \\
\hline Sarı başıl irik tuudu, & Sarı başlı erkek koyun doğdu, \\
\hline Manasındı tuuganda & Manas'ını doğduğunda \\
\hline Tamanı menen tik tuudu! & Ayă̆ına durarak dik doğdu. \\
\hline \multicolumn{2}{|c|}{ S. Karalaev, 2010: 215.} \\
\hline Manas Destanı (Özgün Metin) & Türkiye Türkçesine Aktarımı \\
\hline Tak elüü beş caşında & Tam elli beş yaşında \\
\hline Kan Manastı körüptür. & Han Manasl görmüştür. \\
\hline Sarı saamay kök koydon & Sarı alın saçlı gök koyundan \\
\hline Sarı koçkor irik tuuptur, & Sarı koç doğmuştur, \\
\hline Kara kök cal kabılan & Kara gök yeleli kaplan \\
\hline Kankor Manas dal özün & Kankor Manas'ın kendisini \\
\hline Ayagı menen tik tuuptur. & Ayağına durarak dik doğmuştur. \\
\hline
\end{tabular}

Gördüğümüz gibi buradaki kalıp metinde Manas doğarken sarı alın saçlı gök koyun da sarı başlı koç doğurmaktadır. Bilindiği gibi Türk destanlarında ana kahraman doğduğu gün onun en yakın hayvanı, yani atı doğmaktadır. Örneğin: Manas Destanı'nın ana kahramanı olan Manas ile onun atı Akkula aynı gün dünyaya gelmiştir (Lipets, 1984: 124-127). Demek ki Manas ile aynı gün doğan koç, Manasla özdeşleştirilmektedir. Bir başka deyişle Manas koça benzetilmiştir. Bunun kanıtı şu metinde yer almaktadır (S. Orozbakov, IV. kitap: 209, 93139323):

\begin{tabular}{||l|l||}
\hline \multicolumn{1}{|c|}{ Manas Destanı (Özgün Metin) } & \multicolumn{1}{|c|}{ Türkiye Türkçesine Aktarımı } \\
\hline 'Kökcal Manas mıktı dep, & Gök yeleli Manas cesur diye, \\
Kördüm ele tüşümdö & Görmüş idim rüyamda \\
Çıgırık müyüz kök koçkor & Yuvarlak boynuzlu gök koç \\
Çıga kalıp koroodon & Ortaya çıkıp ağıldan \\
Altından kılgan taktımdı & Altından yapılmış tahtımı \\
Talkalay süzüp cıktı!' dep, & Imha ederek süzdü, yıktı!' diye, \\
Akunbeşim munu aytıp, & Akunbeşim bunu söyleyip, \\
Askerdin baarın muyaytıp & Ordunun tümü üzüldü. \\
\hline \hline
\end{tabular}

Başında Manas bulunan Altay Türklerinin Türkistanı Çinlilerden boşaltma seferi sırasında geçen bu metinde Çüy'ün valisi olan Çinli padişah Akunbeşim, askerlerine rüyasını anlatmaktadır. O, rüyasında onun tahtını yuvarlak boynuzlu gök koçun tahrip edip yıktı̆̆ını 
anlatmaktadır. Bu yuvarlak boynuzlu gök koç da Manastır. Demek ki destanda Manas gök koça benzetilmiştir. Buradaki gök koyun ile gök koçun rengi de ayrı bir anlam taşımaktadır. Çünkü mavi renk Türk kültüründe çok anlama sahip bir renktir. Nitekim mavi, gögün rengidir. Zaten Türkçede gök kelimesi hem mavi rengi, hem de semayı bildirmektedir. Göğün ise Türk devlet anlayışındaki yeri büyüktür. Eski Türk anlayışına göre kağanlar Tanrı tarafından seçilmekte, kağana devleti idare etme yetkisi Tanrı tarafindan verilmekteydi (Koca, 2003: 66-67). Bu durum Bilge Kağan ve Köl Tigin yazıtlarındaki 'tepri teg tejride bolmış türk bilge kagan bu ödke olurtım [(Ben) Tanrı gibi ve Tanrı'dan olmuş Türk Bilge Kăgan bu zamanda tahta oturdum]' cümlesinde görülmektedir. Eski Türk anlayışında ise Tanrı gökyüzündedir. Dolayısıyla Köktürk devletinin bayrağı gök renkteydi (Küçük, 2010: 197). Oğuz Kağan'ın yüzünün ve ordusuna kılavuzluk eden kurdun mavi renkte olması kutsallıkla ve Tanrıyla ilişkilidir. Çünkü mavi genellikle gök rengi olarak kullanıldığı için Tanrı'nın ululuğunun ve yüceliğinin bir göstergesi olarak kabul edilmiştir (Küçük, 2010: 190). Manas Destanı'ndaki Manas'ın benzetildiği, onun bir simgesi olarak yer alan gök koç aynı değeri taşımaktadır. Bir başka deyişle, Manasın yüceliğini, ona devleti idare etme yetkisi Tanrı tarafından verildiğini yansıtmaktadır. Aynı zamanda mavi renk koçun bir kutsal hayvan olduğunu belirtmektedir.

\section{Sonuç:}

- Hacmi ve muhtevası açısından dünyanın en büyük destanlarının başında bulunan Manas Destanı, Eski Türk hayatını, kültürünü yansıttığı için bünyesinde Eski Türkçenin söz varlığını, bu kelimelerde korunan kültürel kodu, inancı da barındırmaktadır. Bunun bir örneği Türk kelimesidir.

- Türkçenin tarihî devirlerinde güçlü, büyük, güzel anlamlarında geçen bu kelime bugünlerde Türk lehçelerinin hiç birinde leksik anlama sahip bir cins kelime olarak kullanılmamaktadır. Kırgız Türkçesinde de bulunmayan Türk kelimesi sadece Manas Destanı'nda Eski Türkçedeki gibi hem güzel, iyi hem de büyük anlamında geçmektedir. Bunun nedeni de söz konusu kelimenin sadece kalıplaşmış mısralarda belirli varlıklar için kullanılmasıdır. Yani Manas Destanı'ndaki Türk kelimesi güzel, iyi anlamında sadece söğüt ve kavak ağaçlarıyla ilgili geçmektedir. Bunun nedeni de söğüt ve kavak ağaçlarının Türk hayatındaki önemiyle, ağaç kültüyle ilişkili olmasıdır. 'Biri terek, biri tal, Cıgaçının türkü oşo (Biri kavak, biri sögüt, A Ăaçlarının güzeli onlar)' mısralarında söğüt ve kavağın ağaçların güzellerinden, iyilerinden olduğu Türk kelimesi aracıllğıyla belirtilmiştir.

- Türk kelimesi Manas Destanı'nda büyük anlamında sadece koyun, koç ve kuzuya ilişkin kullanılmaktadır. Örneğin: 'Koçkordu bakkın türk bolsun (Koçu besle, büyük olsun)' mısraında koçu beslerse Türk, yani büyük olacağı anlatılmaktadır. Büyük anlamına gelen Türk 
kelimesinin destanda sadece koyun, koç ve kuzuyu nitelendirmesi, bize göre bu hayvanların Türk hayatındaki öneminden, kült hayvanlarından olmasından kaynaklanmıştır.

- Türk kelimesinin güzel, iyi ve büyük anlamlarına gelen leksik bir kelime olarak yalnızca Manas Destanı'nda korunmuş olması söz konusu destanın Eski Türk hayatını, kültürünü yansıtan bir destan olması ve bu destandaki ağaç, koyun / koç kültü ile ilişkilidir.

\section{Kaynaklar}

AKSOY, M. (2014). Tarihin Sessiz Dili Damgalar. İstanbul.

AKSOY, M. (2012). “Tunceli' de Koç - Koyun Heykelleri ve Balballar.” 2023 Dergisi, 129, 1620.

AKSOY, M. (2012). “Kazakistan'da Koç - Koyun Heykelli Mezarlar.” Türk Dünyası Tarih Kültür, S 302. C 51, 29-31.

ALYILMAZ, C. (2015). İpek Yolu Kavşağının Ölümsüzlük Eserleri. Ankara: Atatürk Üniversitesi Yay.

ALYILMAZ, C. (2016). “Gobu”stan’ın Gizemi (Klpçaklar'a Giden Yol). Ankara.

ATALAY, B. (1998). Divanü Lûgati-t Türk Tercümesi I, II, III, IV. (4. Bask1). Ankara: TDK Yay.

BARS, M. E. (2014a). Türk Kültüründe Ağaç Kültü ve Şor Kahramanlık Destanlarına Yansimalar1. JASSS The Journal of Academic Social Science Studies, 27, 379-398.

BARS, M. E. (2014b). "Şor Kahramanlık Destanlarında Kalıp İfadelerin Kullanımı.” Akademik Sosyal Araştırmalar Dergisi, 5, 289-308.

ÇAY, A. (1983). Anadolu'da Türk Damgası Koç Heykel - Mezar Taşları ve Türkler'de Koç Koyun Meselesi. Ankara.

DANIK, E. (1993). Koç ve At Şeklindeki Tunceli Mezartaşları. Ankara.

DIYARBEKİRLİ, N. (1972). Hun Sanatı. İstanbul: Kültür Yay.

ERCiLASUN, A. B. ve AKKOYUNLU, Z. (2014). Kâşsgarlı Mahmud, Dîvânu Lugâti't-Türk, Giriş-Metin-Çeviri-Notlar-Dizin. Ankara: TDK Yay.

ERGUN, P. (2004). Türk Kültüründe Ağaç Kültü. Ankara.

GEYİKOĞLU, H. (2001). "Tarih Açısından Manas Destanı ve Sovyetler Birliği’ndeki Türklerin Millî Duygularına Etkisi.” Atatürk Üniversitesi Türkiyat Araştırmaları Enstitüsü Dergisi, 6, 201-207.

GÜRSOY, Ü. (2012). “Türk Kültüründe Ağaç Kültü ve Dut Ağac1.” Türk Kültürü ve Hacı Bektaş Veli Araştırma Dergisi, 61, 43-54.

KARALAEV S. (2010). Manas: Baatırdik Epos (haz. Caynakova, Aynek ve Akmataliev, Abdıldacan), Bişkek: Kırgız Bilimler Akademisi yayınları,.

KOCA, S. (2003). Türk Kültürünün Temelleri. (II. Cilt). Ankara.

KÜÇÜK, S. (2010). “Eski Türk Kültüründe Renk Kavramı.” Bilig, 54, 185-210.

LíPETS. R. S. (1984). Obrazı Batıra i Ego Konya v Tyurko-Mongolskom Epose. Moskova: Nauka.

MERT, O. (2009). Ötüken Uygur Dönemi Yazıtlarından Tes, Tariat, Şine Us. Ankara. 
MERT, O. (2015). Köli Çor Yazıtı ve Anıt Mezar Kompleksi. Ankara.

MERT, O. (2007). “Kazak Türkçesi’nde Hayvan Adlarıyla Kurulan Atasözleri.” Kazakistan ve Türkiye’nin Ortak Kültürel Değerleri Uluslararası Sempozyumu Bildirileri 21-23 Mayıs 2007, Almaata, 297-312.

NADELYAYEV V. M. vd., (1969). Drevnetyurkskiy Slovar. Leningrad: Nauka.

ORKUN, H. N. (2011). Türk Sözünün Aslı. (2. Bask1). Ankara: TDK Yay.

OROZBAKOV, S. (1995). Manas: Baatırdık Epos I. Kitap. (haz. Musaev, Samar vd.). Bişkek: Kırgız Bilimler Akademisi Yay.

OROZBAKOV, S. (1995). Manas: Baatırdık Epos II. Kitap. (haz. Musaev, Samar vd.). Bişkek: Kırgiz Bilimler Akademisi Yay.

OROZBAKOV, S. (1995). Manas: Baatırdık Epos III. Kitap. (haz. Musaev, Samar vd.). Bişkek: Kırgız Bilimler Akademisi Yay.

OROZBAKOV, S. (1995). Manas: Baatırdlk Epos VIII ve IX. Kitap. (haz. Musaev, Samar vd.). Bişkek: Kırgız Bilimler Akademisi Yay.

ÖGEL, B. (1993). Türk Mitolojisi. (Kaynakları ve Açıklamaları ile Destanlar). (I. Cilt). Ankara: TTK Yay.

ÖGEL, B. (1995). Türk Mitolojisi. (Kaynakları ve Açılamaları ile Destanlar). (II. Cilt). Ankara: TTK Yay.

ÖĞER, A. ve GÖNEL, T. (2011). "Uygur Türkleri Arasında Şamanlar ve Tedavi Yöntemleri.” Turkish Studies, 6(4), 233-248.

RAIHL, K. (2008). Tyurkskiy Epos: Traditsii, Formı, Poetiçeskaya Struktura. Moskova: Vostoçnaya Literatura.

TÜRKMEN, F. (2008). “Azerbaycan'daki Koç Şekilli Mezar Taşlarının Folklorik Açıdan Değerlendirilmesi." Prof. Dr. Ahmet Bican ERCiLASUN Armağanı, Ankara: Akçağ Yay., 503-513.

ÜSTÜNER, A. (2014). "Hârezmli Hâfız Divanında Türk Adı." Turkish Studies, 9(6), 11071116.

YILDIZ, N. (1998). "Dede Korkut Hikâyelerinde ve Manas Destanında Ağaç.” Millî Folklor, $37,47-51$.

YUDAHIN, K. K. (1985). Kirgizsko-Russkiy Slovar' II. Frunze: Kırgız Ansiklopedisi Yay. 


\section{Ekler:}

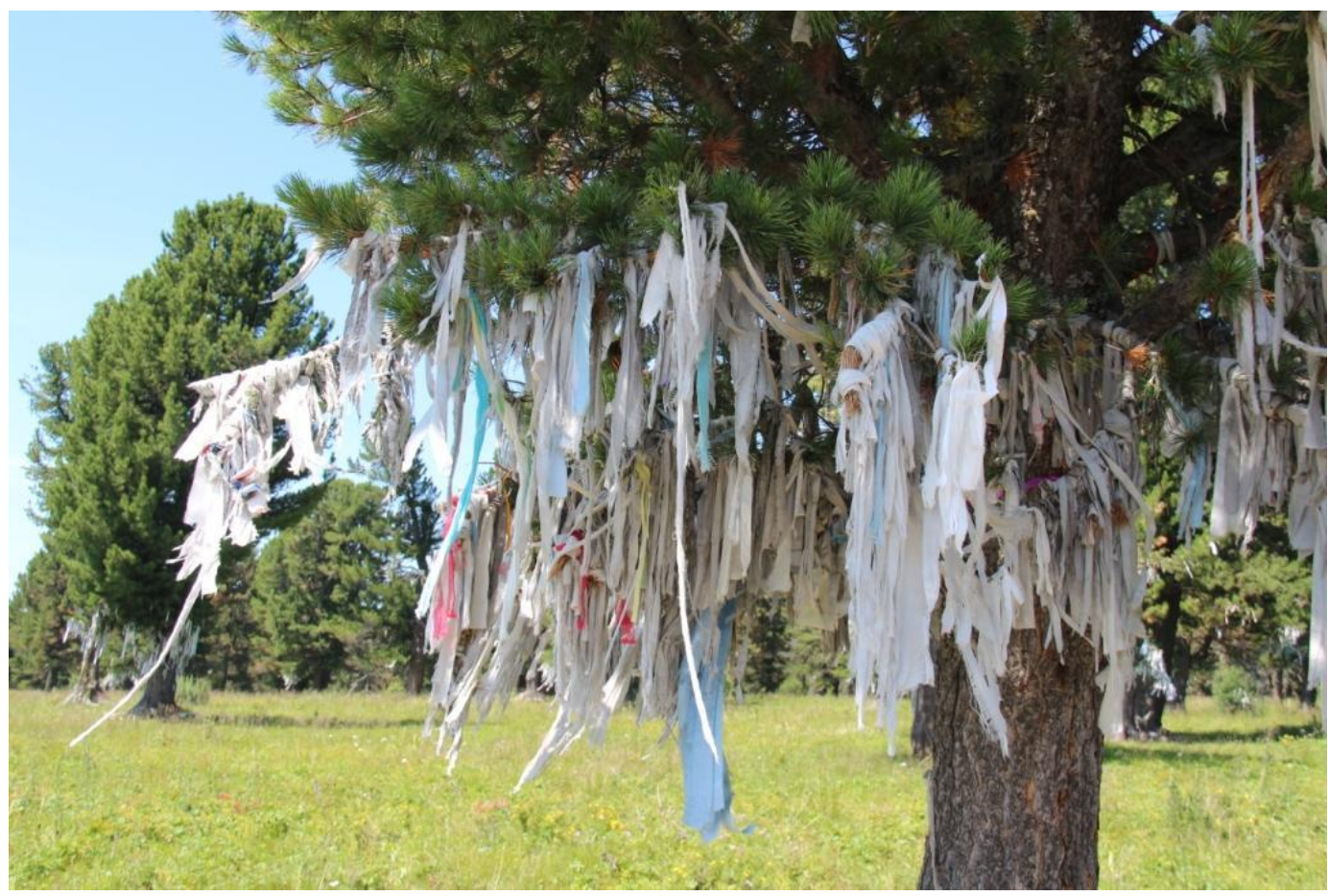

Foto 1: Kutsal sayıldı̆̆ı için dallarına bez bağlanan çam ağacı, Dağlık Altay (Foto: N. Useev)

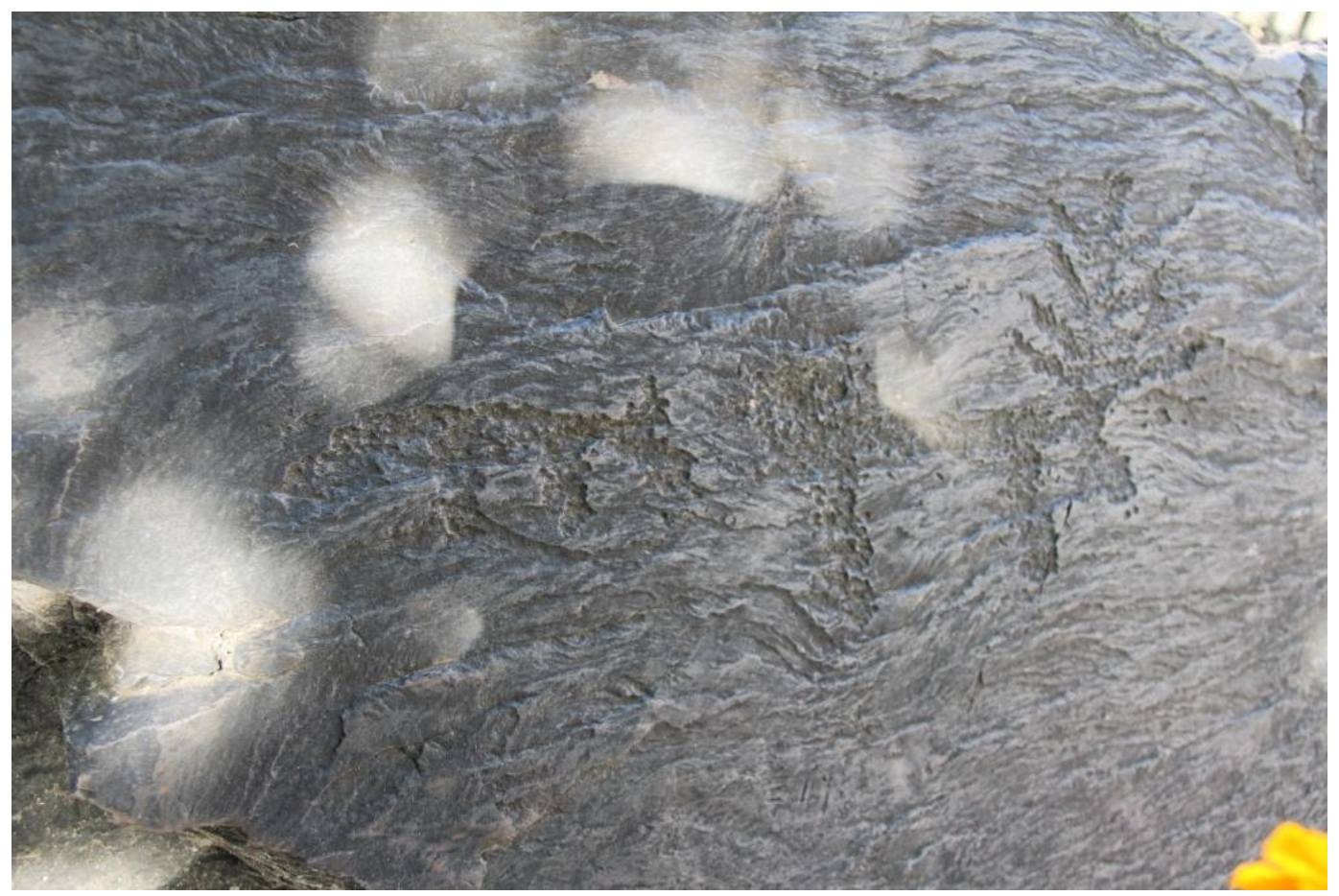

Foto 2: Boynuzu hayat ağacına benzetilen geyik tasviri, Hakasya (Foto: N. Useev) 


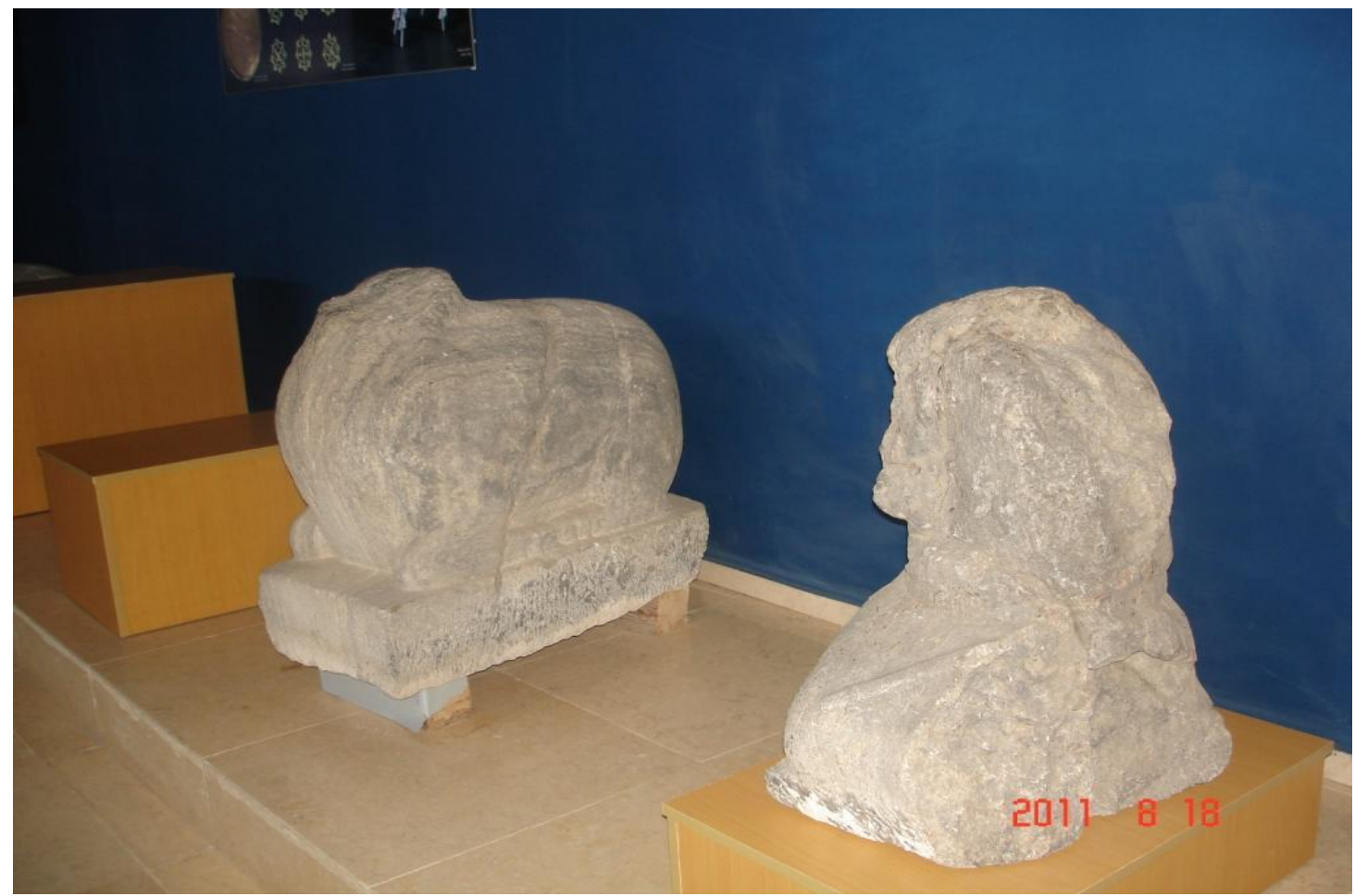

Foto 3: Bilge Kağan Mezar Kompleksi’nden çılkarılan kafası kırılmış koç heykeli (Foto: N. Useev)

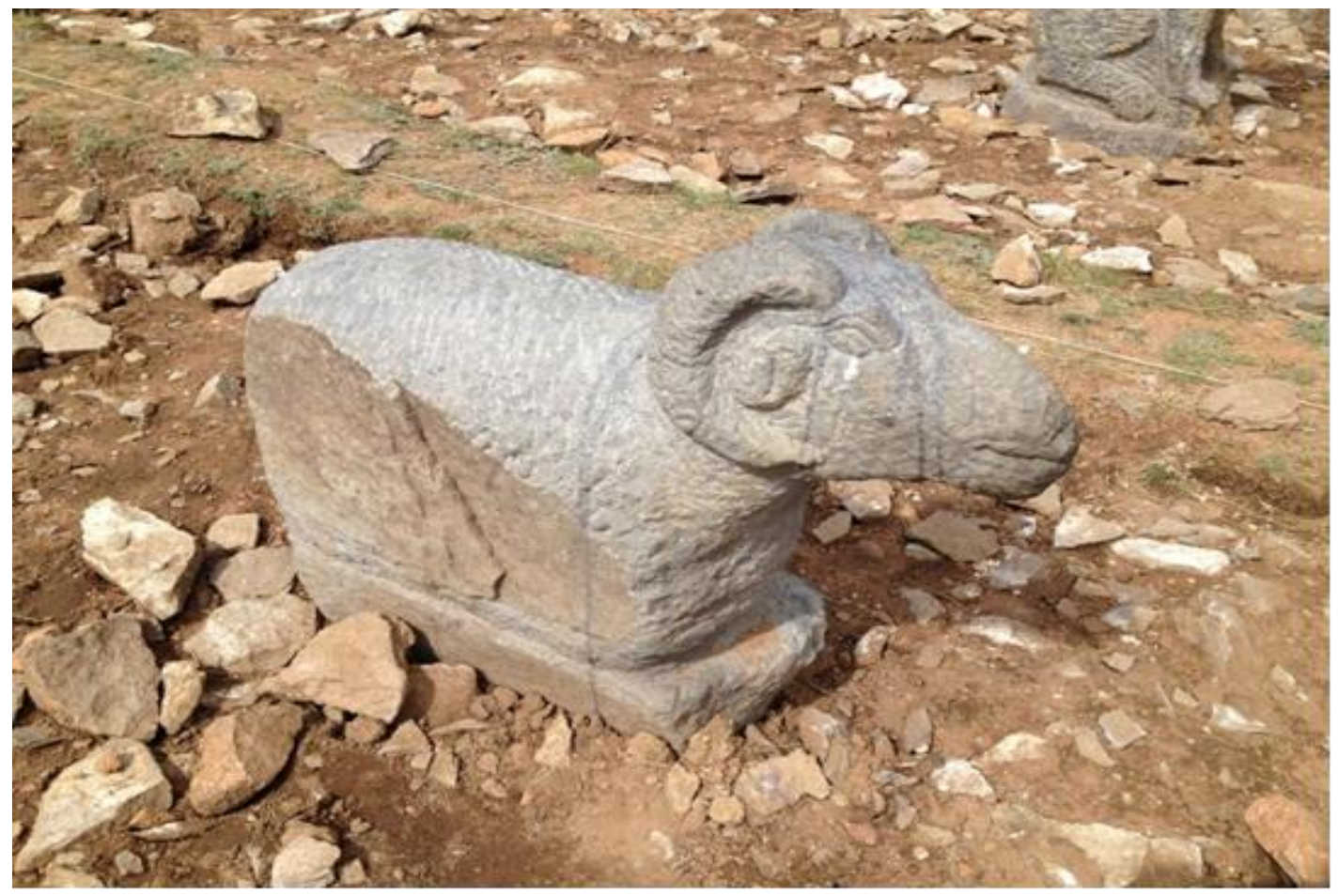

Foto 4: Şivet Ulaan (İlteriş Kağan) Mezar Kompleksi'nden çıkarılan koç heykeli (Foto: N. Useev) 


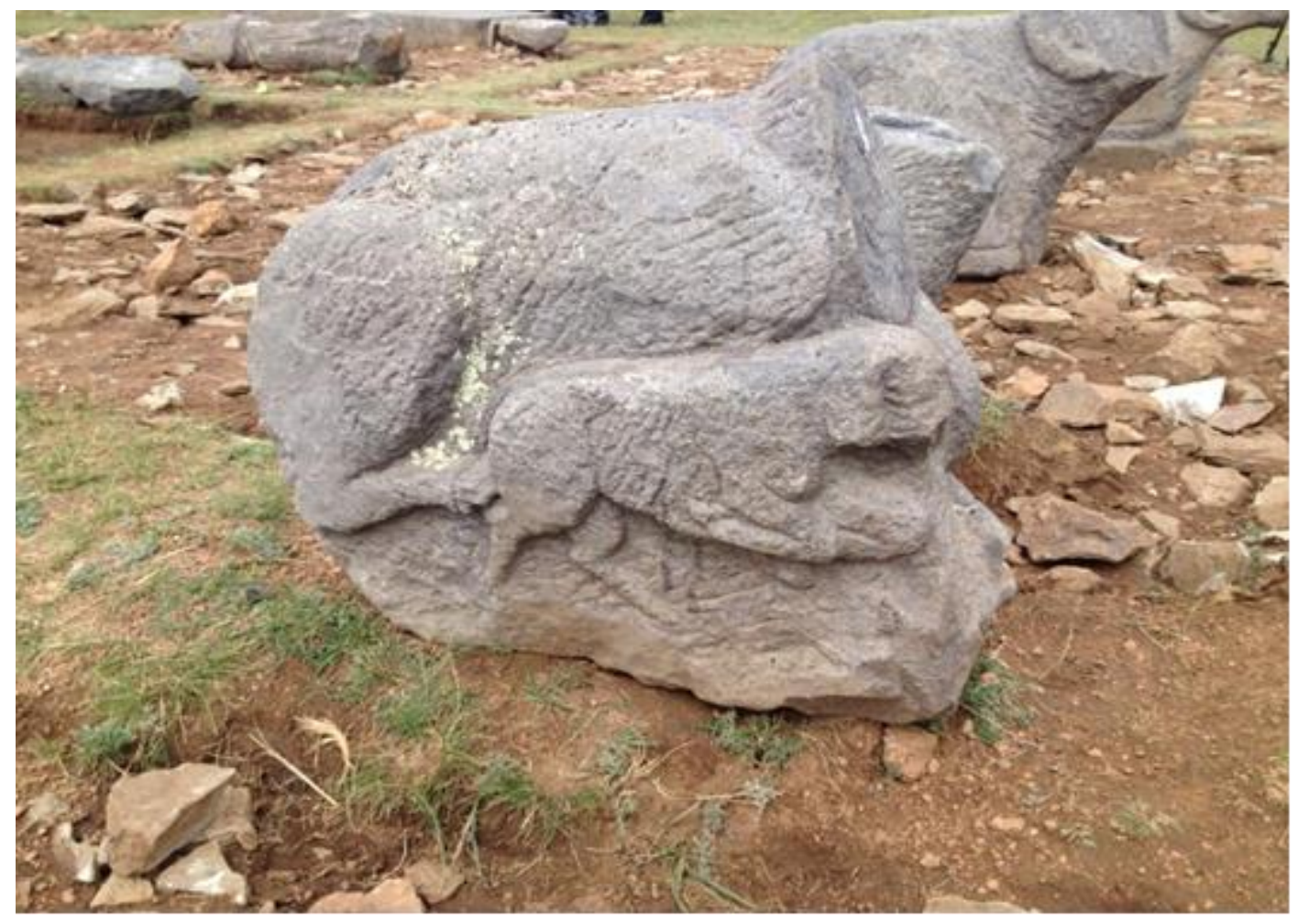

Foto 5: Şivet Ulaan (İlteriş Kağan) Mezar Kompleksi'nden çıkarılan kuzulu koyun heykeli (Foto: N. Useev) 